Jap. J. Limnol. 41, 2, 84-94, 1980

\title{
Some Considerations on the Dense Population of a Purple Sulfur Bacterium, Chromatium sp., at the Mid-depth of Lake Kaiike
}

\author{
Michiro MATSUYAMA
}

\begin{abstract}
The purpose of the present study is to consider the dense population of a purple sulfur bacterium, Chromatium sp., at the mid-depth of Lake Kaiike on Kamikoshiki Island. In summer (1979), the lake was well stratified and at the boundary $(4.75 \mathrm{~m})$ between upper $\mathrm{O}_{2}$ and deeper $\mathrm{H}_{2} \mathrm{~S}$ layers a dense population $\left(5 \times 10^{6} \mathrm{cells} / \mathrm{ml}\right)$ of Chromatium sp. was found. A hyperbolic relation between the bacterial growth and $\mathrm{H}_{2} \mathrm{~S}$ concentration obtained in the laboratory experiment indicates that the in situ growth of Chromatium sp. is controlled by the supply of $\mathrm{H}_{2} \mathrm{~S}$ from the reducing deeper water where it accumulated. The facts that further penetration of light beyond the mid-depth was greatly limited by self-shading of Chromatium sp. and that the carbon assimilation at this depth by the bacterium occupied a substantial part of the whole process in the lake suggest that the bacterium also has an important role in the formation and maintenance of the reducing condition of deeper water.
\end{abstract}

\section{Introduction}

A stratified lake exhibits many interesting chemical and biological phenomena due to its characteristic physical condition. The bottom part is in great contrast to the upper part and frequently contains an $\mathrm{H}_{2} \mathrm{~S}$ layer. Sharp gradients of temperature and dissolved $\mathrm{O}_{2}$ are found between the two layers. Different kinds of microorganisms are noted to be sequentially layered at respective depths to meet environmental and biological requirements without undergoing the disturbance of vertical mixing (Gorlenko and Kuznetsov, 1972; KuZNetsov and Gorlenko, 1973; CALdWell and Tiedje, 1975a, b; Gorlenko et al., 1978). Hence, a stratified lake offers an ideal field for the study of the relationships between environment and organisms or the biological interactions among different organisms, which are rather difficult to evaluate in well-mixed waters. Due to a limited vertical water motion, specific composition of the phytoplankton that could form stable populations is limited
(FogG, 1965; Hutchinson, 1967). On the other hand, some of the photosynthetic and chemosynthetic bacteria play an important role in organic matter production therein (Czeczuga, 1968; Culver and BRUNSKILl, 1969; TAKAHASHI and ICHIMU RA, 1970; Matsuyama and Saijo, 1971; CoHen et al., 1977).

The author has made a number of studies on a small stratified lake, Kaiike (Matsuyama, 1977, 1978, 1979; MatsuYAMA and Shirouzu, 1978) on Kamikoshiki Island. The present study deals with evaluating possible mechanism of forming a dense bacterial plate of a purple sulfur bacterium, Chromatium sp., at its middepth.

\section{Methods}

The data were obtained from field observations at Lake Kaiike between 31 July and 1 August, 1979, and from laboratory experiments on the growth of Chromatium sp., which was isolated from the lake in November, 1978.

Samplings in the lake were made at the 


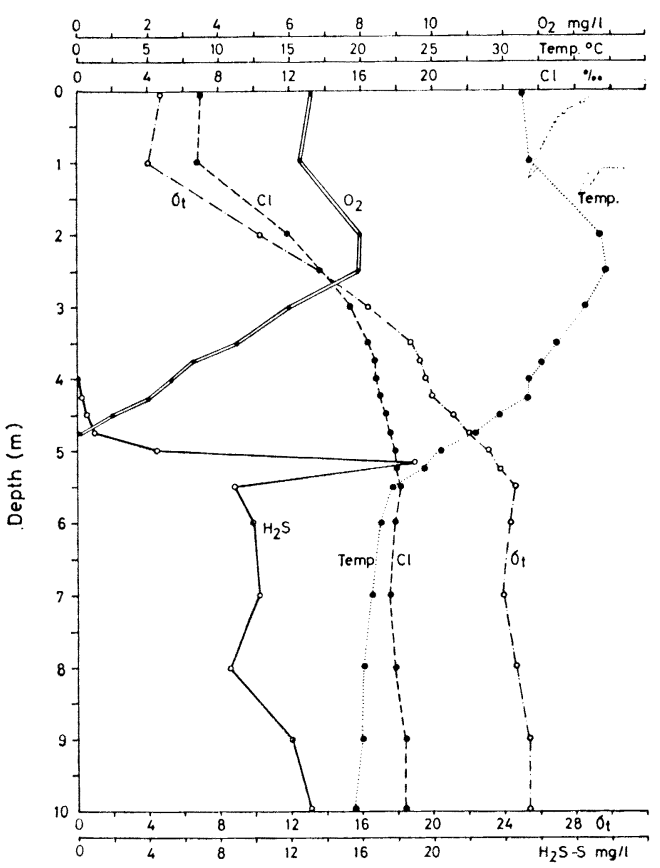

Fig. 1-A

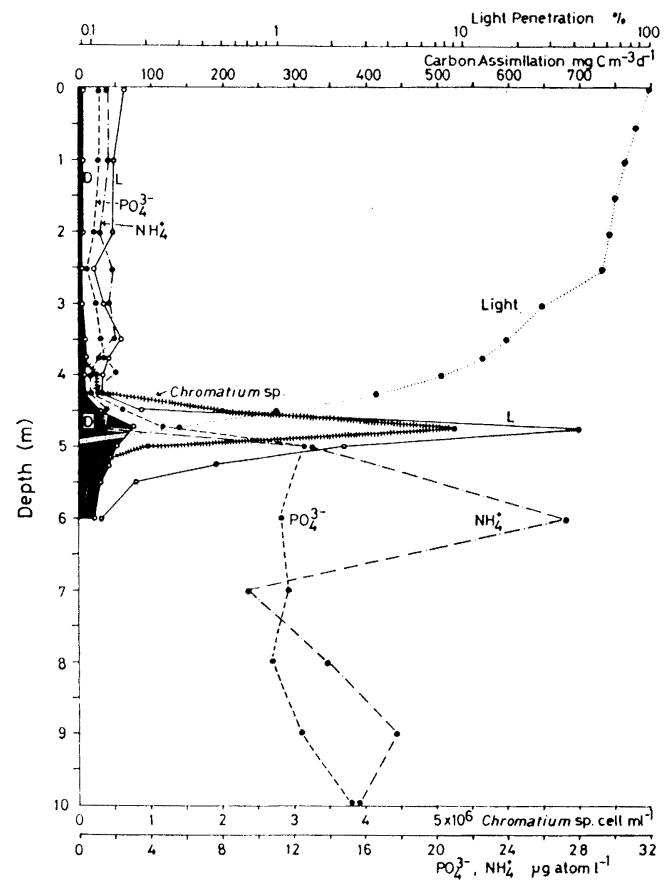

Fig. 1-B

Fig. 1. Vertical distributions of some environmental factors, carbon assimilation rate and Chromatium sp. in Lake Kaiike (31 July, 1979). A: vertical distributions of chlorinity, temperature, $\sigma_{t}$, dissolved $\mathrm{O}_{2}$ and $\mathrm{H}_{2} \mathrm{~S}$. B: vertical distributions of relative light intensity, $\mathrm{NH}_{4}^{+}, \mathrm{PO}_{4}^{3-}$, carbon assimilation rates in light (L) and dark (D) bottles, and Chromatium sp. Light intensity at $5 \mathrm{~m}$ was $0.02 \%$ of just below the surface.

point of a maximum depth, using an acrylic sampler having a $2.5 l$ capacity. A glass thermometer was used for the measurement of temperature. Chlorinity was determined by the MOHR-KNUDSEN method. Dissolved $\mathrm{O}_{2}$ was measured by the WINKLER method, but a modified method (INGVORSEN and JøRGENSEN, 1979) was applied at low dissolved $\mathrm{O}_{2}$ concentration. $\mathrm{H}_{2} \mathrm{~S}$ was determined by the iodometric titration method of CdS precipitate (AMERICAN Public Health Association, 1965). Samples for $\mathrm{NH}_{4}^{+}$and $\mathrm{PO}_{4}^{3-}$ determinations were passed through a glass fiber filter and frozen for storage in polyethylene bottles. Both nutrients were determined by the indo-phenol and DENIGẼS meth- ods, respectively, in the laboratory (Oceanographical Society of Japan, 1970). Samples for enumeration of Chromatium sp. were kept under cool and dark and cell density was counted with a brightline haemocytometer within 5 hours after collection. Carbon assimilation rate was measured by the in situ method using ${ }^{14} \mathrm{C}_{-}-\mathrm{HCO}_{3}^{-}$(Steemann Nielsen, 1952).

The Fuller's inorganic medium described by BOSE (1963) was employed for isolation and subsequent culture experiments. The composition of the medium and the method of culture were given in the previous study (Matsuyama, 1979). The culture was not monospecific, but the biomass of other microorganisms was 
judged by microscopic inspection to be less than $1 \%$ of the biomass of Chromatium sp. The experiments of the effects of $\mathrm{H}_{2} \mathrm{~S}$ and inorganic nutrients on Chromatium sp. growth were conducted with the bacterium in the later exponential growth phase when cell density was nearly of the order of $10^{9}$ cells $/ \mathrm{m} l$. Cells were separated from the medium by two successive centrifugations. Then, the bacterium was resuspended into a series of bottles filled with medium from which sulfur, nitrogen or phosphorus was previously depleted. $\mathrm{Na}_{2} \mathrm{~S}, \mathrm{NH}_{4} \mathrm{Cl}$ or $\mathrm{NaH}_{2} \mathrm{PO}_{4}$ was added to give a series of varied concentrations. Then, the bottles were tightly stoppered and incubated at a constant temperature of $30^{\circ} \mathrm{C}$ and continuously illuminated with incandescent lamps at 2000 lux. After 1-2 days of incubation, the cell density was determined daily with a haemocytometer.

\section{Results}

\section{Field Observations}

Fig. 1 shows the vertical distributions of some environmental factors in Lake Kaiike together with the carbon assimilation rate and Chromatium sp. in July, 1979.

Chlorinity of surface water was about $7 \%$, but it increased in the layer from $1 \mathrm{~m}$ to $5.5 \mathrm{~m}$ depth, where it attained to $18 \%$. Below this level a slight decrease was found at around $7 \mathrm{~m}$. The bottom water had a chlorinity of $18.42 \%$. Water temperature was about $31^{\circ} \mathrm{C}$ at the surface and increased notably at $2-2.5 \mathrm{~m}$ layer, attaining to a maximum of about $37^{\circ} \mathrm{C}$. Then, temperature decreased rapidly down to $5.5 \mathrm{~m}$. Below this level water had a relatively constant temperature of about $20^{\circ} \mathrm{C}$. $\sigma_{\mathrm{t}}$, calculated from chlorinity and temperature, increased consistently in the water from $1 \mathrm{~m}$ to $5.5 \mathrm{~m}$, indicating that this layer was stably stratified. Light penetration in Lake Kaiike showed that light easily passed through the upper water, but below $2.5 \mathrm{~m}$ the light transmission deteriorated and was notably poor below $4 \mathrm{~m}$. Dissolved $\mathrm{O}_{2}$ was saturated in the surface. A marked maximum was observed at the layer from $2 \mathrm{~m}$ to $2.5 \mathrm{~m}$. Below this layer it decreased rapidly with depth and ultimately disappeared at $4.75 \mathrm{~m} . \mathrm{H}_{2} \mathrm{~S}$ began to appear at $4 \mathrm{~m}$ and increased with depth attaining to a maximum of $19 \mathrm{mg} \mathrm{S} / \mathrm{l}$ at $5.5 \mathrm{~m}$. Concentrations of $\mathrm{HN}_{4}^{+}$and $\mathrm{PO}_{4}^{3-}$ were low in the upper water, usually less than $1 \mu \mathrm{g}$ atom/l. But they accumulated in the deeper water below $4.75 \mathrm{~m}$. Maximum concentrations of $\mathrm{NH}_{4}^{+}$and $\mathrm{PO}_{4}^{3-}$ were 27 and $15 \mu \mathrm{g}$ atoms $/ l$, respectively. The accumulation of $\mathrm{NH}_{4}^{+}$in the present observation, however, was slight compared with the previous observations (MATsuyama and Shirouzu, 1978). Carbon assimilation rates by phytoplankton were low, usually less than $50 \mathrm{mg} \mathrm{C} \mathrm{m}^{-3}$ day $^{-1}$. But a significant assimilation was observed around the $\mathrm{O}_{2}-\mathrm{H}_{2} \mathrm{~S}$ boundary at $4.75 \mathrm{~m}$, attaining to $700 \mathrm{mg} \mathrm{C} \mathrm{m} \mathrm{m}^{-3}$ day $^{-1}$. Chromatium $\mathrm{sp}$. appeared at $4 \mathrm{~m}$ and the bacterial density reached a maximum of $5.2 \times 10^{6}$ cells $/ \mathrm{ml}$ at $4.75 \mathrm{~m}$. Below this level, however, the bacterial density rapidly decreased and the bacterial count was no longer significant at $6 \mathrm{~m}$.

Fig. 2 shows a microscopic photograph of suspended particles at $4.75 \mathrm{~m}$. A substantial part of them was occupied by Chromatium sp. cells, although a considerable number of unknown microorganism, having a cell size similar to Chromatium sp. but fusiform in shape, was also found.

\section{Laboratory Experiments}

Fig. 3 shows the growth of Chromatium sp. cultured at different temperature between $10-38^{\circ} \mathrm{C}$. The bacterium grew fast with increase in temperature up to $32^{\circ} \mathrm{C}$. But above the temperature the bacterial growth rapidly decreased. Relationships between the maximum growth rates 


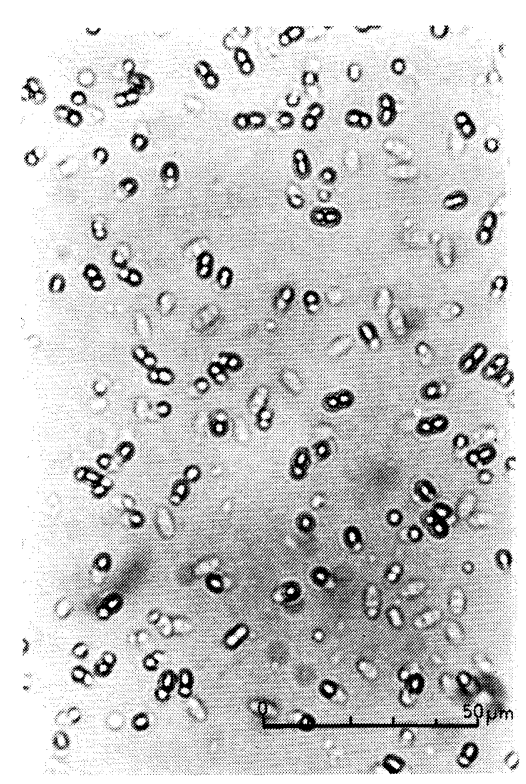

Fig. 2. Microscopic photograph of suspended particles in the bacterial plate of Lake Kaiike. Most of them were occupied by Chromatium sp. cells.

(base e) which each curve shows and temperature (reciprocal of absolute temperature) are shown in Fig. 4, in which those for freshwater and marine algae reported by Goldman and CARPENTER (1974) are also given. The relationship for Chromatium sp. between 10 and $32^{\circ} \mathrm{C}$ could be expressed by the equation

$$
\mathrm{k}=9.96 \times 10^{9} \mathrm{e}^{-6278 \mathrm{~T}}
$$

This equation represents a $\mathrm{Q}_{10}$ of 2.16. Since the upper limit of growth rates obtained from many cultures of the bacterium under different conditions come to these points, these figures seem to show the maximum one which the bacterium intrinsically has.

Fig. 5 summarizes the growth of Chromatium sp. cultured in the media to which different amounts of $\mathrm{Na}_{2} \mathrm{~S}$ were added as the sole sulfur source. (Most $\mathrm{Na}_{2} \mathrm{~S}$ will be altered into forms of $\mathrm{H}_{2} \mathrm{~S}$ and $\mathrm{HS}^{-}$ in terms of the $\mathrm{pH}$ of the media.) Many of the culture entered the exponential growth phase immediately after 2 days of inoculation. The final yields of the bacterium were proportional to the amounts of $\mathrm{Na}_{2} \mathrm{~S}$ added. Relationships between the amounts of $\mathrm{Na}_{2} \mathrm{~S}$ and the growth rates of the bacterium at the beginning of the exponential growth phase during 2 and 3 days after inoculation are given in Fig. 6. As seen in the figure, there was a hyperbolic relation and the half-saturation constant (the concentration supporting half the maximum growth rate), which could be obtained from a linear transformation of the Michaelis-Menten equation, was about $13 \mathrm{mg} \mathrm{S} / l$. Gemerden (1974) studied the coexistence of large and small Chromatium (Chr. vinosum and weissei) competing for the same substrate and showed that the Michaelis-Menten equations exist between the growth rates of both species and $\mathrm{Na}_{2} \mathrm{~S}$ added, but the half-saturation constants were remarkably smaller than the present one: $0.007 \mathrm{mM}$ for $C h r$. vinosum (maximum growth rate: 0.117 $\mathrm{hr}^{-1}$ ) and $0.010 \mathrm{mM}$ for Chr. weissei (maximum growth rate: $0.040 \mathrm{hr}^{-1}$ ).

Figs. 7 and 8 show the growth of Chromatium sp. in the media to which different amounts of $\mathrm{NH}_{4}^{+}$and $\mathrm{PO}_{4}^{3-}$ were added as the sole nitrogen or phosphorus sources. As with $\mathrm{Na}_{2} \mathrm{~S}$, the final yields of the bacterium were proportional to the amounts of $\mathrm{NH}_{4}^{+}$and $\mathrm{PO}_{4}^{3-}$ added.

\section{Discussion}

As seen in Fig. 4, Chromatium sp. has a lower growth rate than freshwater and marine algae at all temperature examined. If all environmental conditions were optimal, the algae would be the successful competitor in the lake, because of its higher growth rate (GoLDMAN and CARPENTEr, 1974). Neverthless, Chromatium sp has always a substantial role in the organic matter production in the lake and phytoplanktonic production is of secondary importance. 


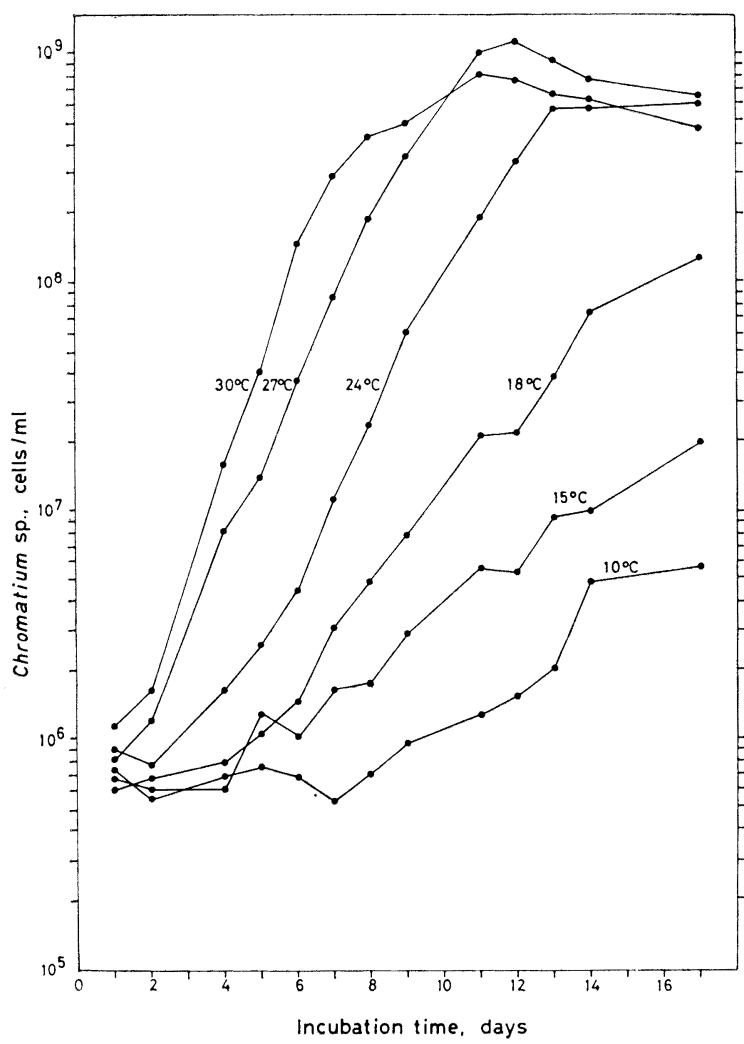

Fig. 3-A

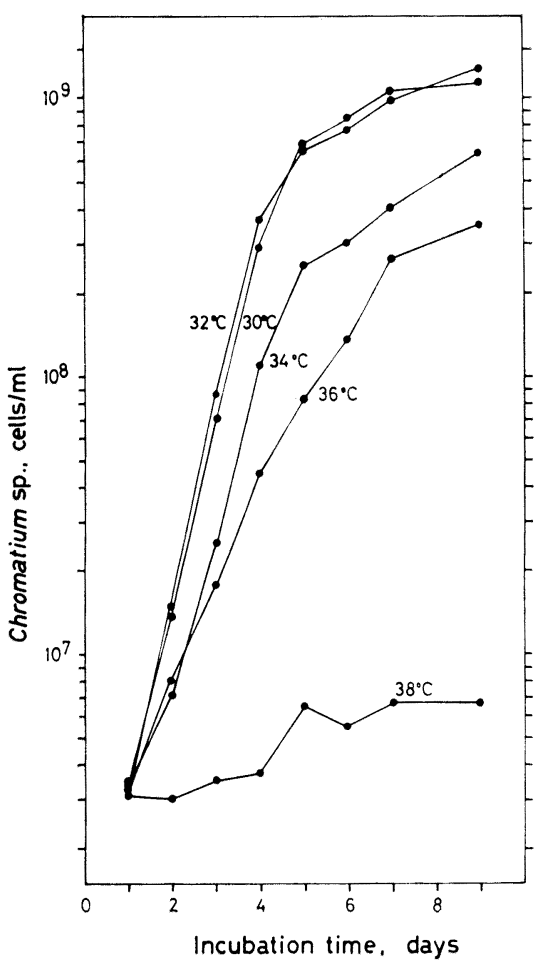

Fig. 3-B

Fig. 3. Effect of temperature on the growth of Chromatium sp. A: $10-30^{\circ} \mathrm{C}, \mathrm{B}: 30-38^{\circ} \mathrm{C}$.

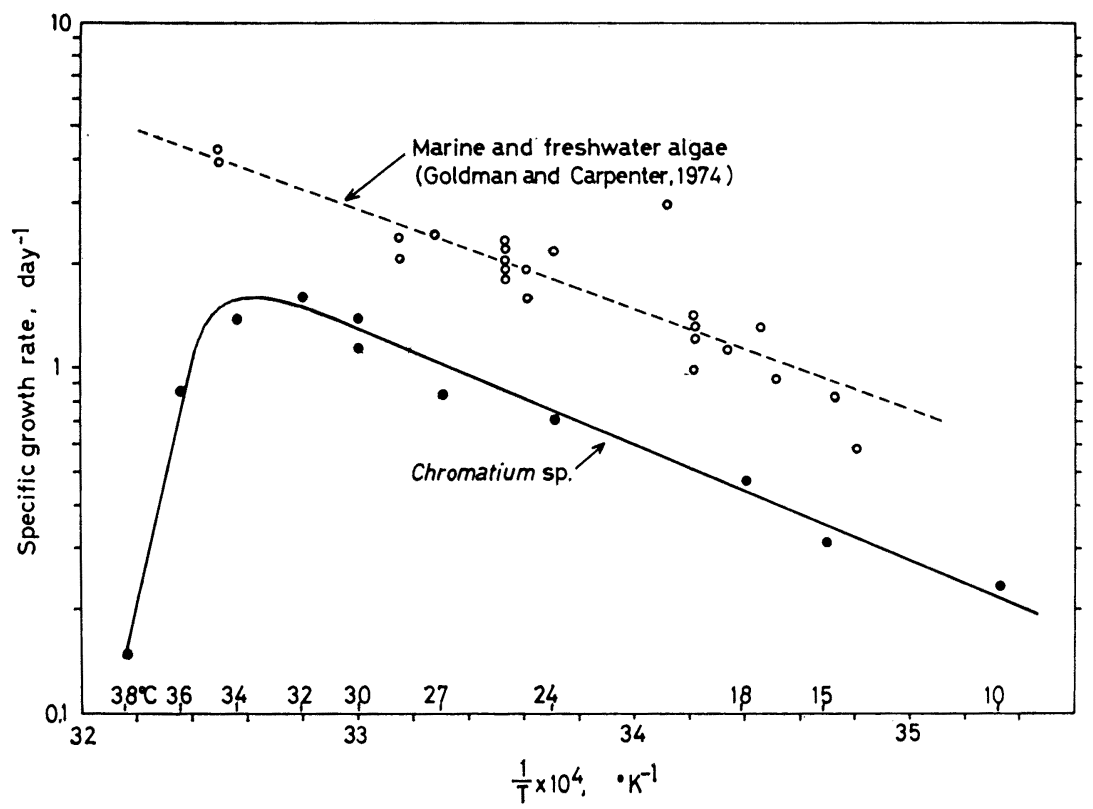

Fig. 4. Effect of temperature on the maximum specific growth rate of Chromatium sp. Maximum growth rate is to the base e. 
As shown in Fig. 6, there exists a hyperbolic relation between the growth rates of Chromatium sp. at the initial exponential phase of culture and the amount of $\mathrm{Na}_{2} \mathrm{~S}$ added; the half-saturation constant was approximated as $13 \mathrm{mg} \mathrm{S} / l$. Hence, Chromatium sp. growth would be expected to be closely determined by the amount of $\mathrm{H}_{2} \mathrm{~S}$ below the half-saturation constant. Actual concentration of $\mathrm{H}_{2} \mathrm{~S}$ in the layer of the bacterial plate of Lake Kaiike has always been shown to be less than $4 \mathrm{mg} \mathrm{S} / l$, so the in situ growth of the bacterium would be obviously controlled by the $\mathrm{H}_{2} \mathrm{~S}$ supply from the deeper water.

As seen in Fig. 1, inorganic nutrients such as $\mathrm{NH}_{4}^{+}$and $\mathrm{PO}_{4}^{3-}$ were poor in the upper water above the bacterial plate, but below the plate they accumulated significantly. The deeper nutrient-rich water is covered with the bacterial plate. Since the deeper water of Lake Kaiike is gradually replaced by seawater seeping through the gravel bar, influenced by annual change in water level in the sea, and is lifted and discharged into an adjacent lake in a diluted form (MATSUYAMA, 1978), these nutrients must be rapidly metabolized into bacterial cells at the plate as suggested from Figs. 7 and 8. That is to say, the inorganic nutrients produced in the deeper water seem to be preferentially used at the bacterial plate and only a limited fraction could be used by phytoplankton above it.

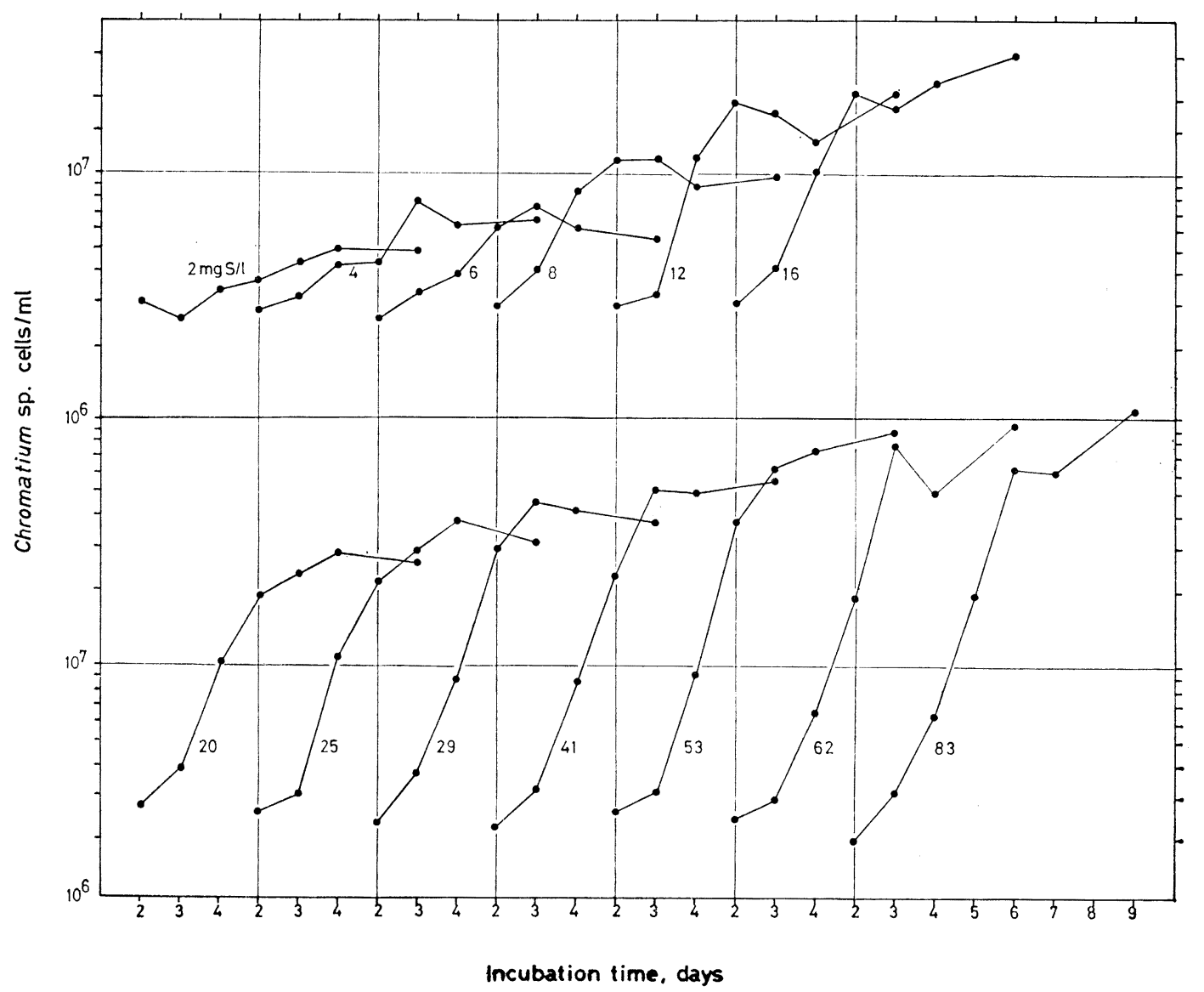

Fig. 5. Growth of Chromatium sp. incubated in the media to which different amounts of $\mathrm{Na}_{2} \mathrm{~S}$ were added. The horizontal line indicates the incubation time (days) after inoculation. 
As shown in the previous study (MATsUy AMA, 1979), Chromatium sp. can grow even under limited light intensity, i.e., as low as about 50 lux, and the bacterium grows fast with increase in light intensity up to about 2000 lux. However, as shown in the same study, the bacterium can thrive only below the algal compensation depth which is usually taken as th depth showing a maximum light intensity of 400-600 lux (Ichimura, 1956). Thus, the range of light intensity available for Chromatium sp. seems to be limited.

As seen in Fig. 1, incident light was remarkably attenuated in the water below $4 \mathrm{~m}$. Chromatium sp. plays a positive role in this reduction of penetrating light, because the bacterium was an important component of suspended particles in this layer (Fig. 2). A significant decrease in light intensity was also noted in the water

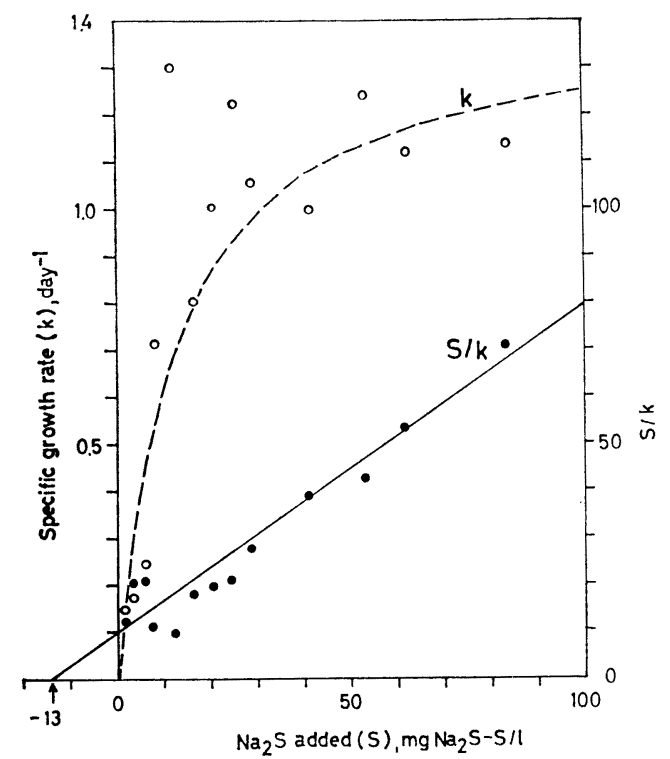

Fig. 6. Relationships between the growth rate of Chromatium sp. (k) during 2 and 3 days of incubation shown in Fig. 5 and the amount of $\mathrm{Na}_{2} \mathrm{~S}(\mathrm{~S})$ added to the media. The half-saturation constant (13 $\mathrm{mg} \mathrm{S} / l$ in this case) is given as the negative $\mathrm{S}$-intercept of the linear regression of $\mathrm{S} / \mathrm{k}$ vs. $\mathrm{S}$. immediately above $4 \mathrm{~m}$, and one of the factors involved is probably zooplankton which densely swarmed there to feed on the bacterium (Matsuyama and Shirouzu, 1978).

Therfore, the fact that Chromatium sp. is always found as a thin layer horizontally extending over a whole basin covering the surface of the deeper water may be due not only to the fact that the bacterial habitat is restricted below the algal compensation depth, but also to the fact that light penetration beyond this depth is rapidly attenuated by self-shading of Chromatium sp. The lower part of the bacterial plate seems to be in virtual darkness.

Since $\mathrm{O}_{2}$ is not liberated as a waste product in the bacterial photosynthesis as in the photosynthesis of algae, production of organic matter by bacterial photosynthesis below the algal compensation depth and subsequent downward flux of organic matter seem to intensify the dissimilatory processes and bacterial sulfate reduction in the underlying water. [Both processes are probably closely interrelated, as suggested in Lake Nitinat and Lake Suigetsu (Richards et al., 1965; MAtSUyAma and SAIJO, 1971).] Furthermore, some species of Chromatium have been known to produce $\mathrm{H}_{2} \mathrm{~S}$ in the dark; they oxidize the reserve food materials coupled with the reduction of previously stored intracellular sulfur to $\mathrm{H}_{2} \mathrm{~S}$ (TRüpper and Schlegel, 1964; Gemerden, 1968). So, Chromatium sp. at the bacterial plate may be directly or indirectly responsible for the formation of the underlying reducing condition.

At all depths below the algal compensation depth, there is a consumption of dissolved $\mathrm{O}_{2}$ by respiratory activity of organisms, so an $\mathrm{O}_{2}$ deficient condition will inevitably appear in the bottom part, if only vertical water motion is limited. Neverthless, it is doubtful whether, even if the lake is stably stratified, such a 


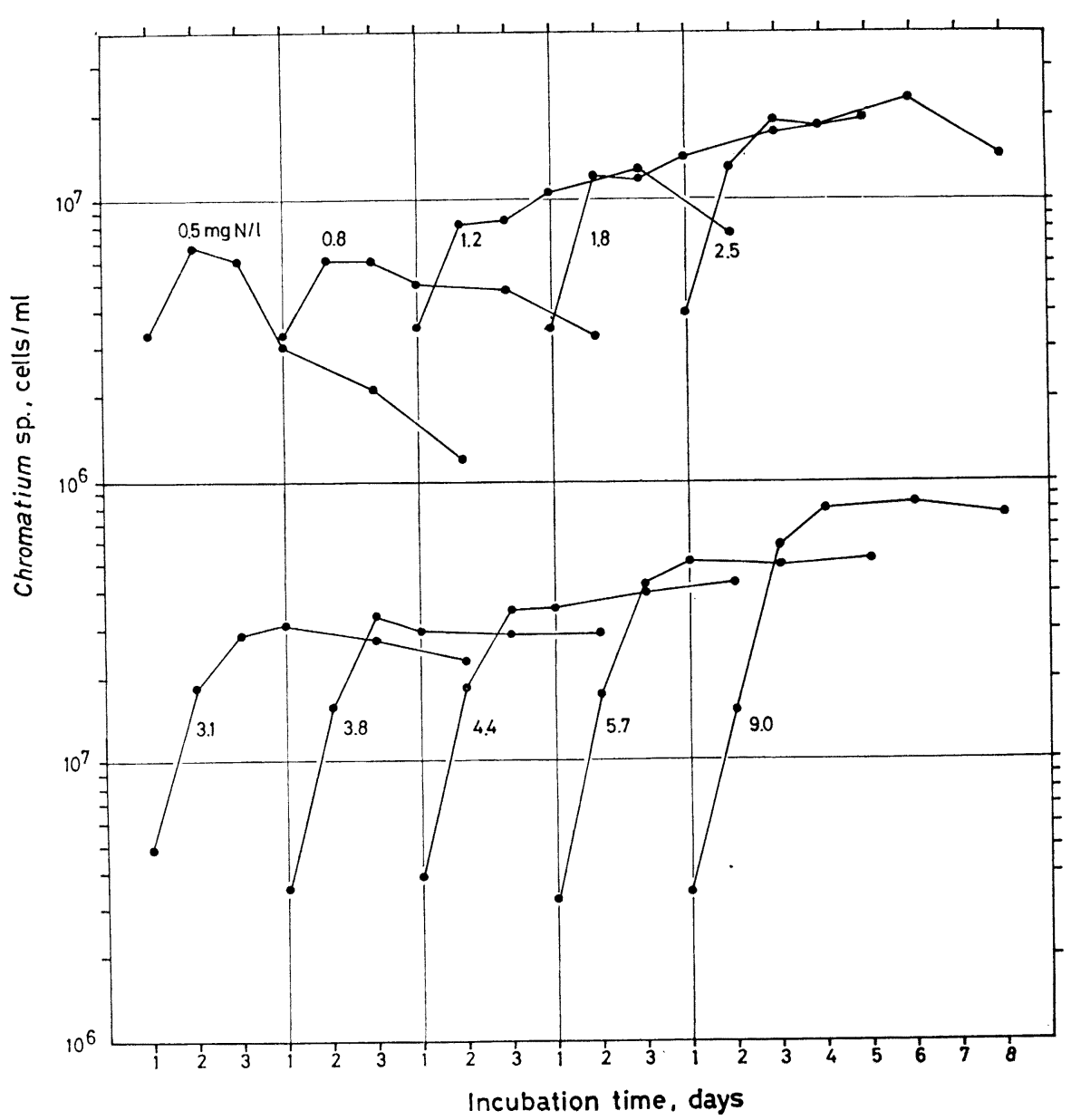

Fig. 7. Growth of Chromatium sp. in the media to which different amounts of $\mathrm{NH}_{4}^{+}$were added. The horizontal line indicates the incubation time (days) after inoculation.

highly reducing condition appear and persist for a long period without the bacterial plate at its upper margin, because more light will penetrate into the deeper layer, if it is absent. It is, therefore, safe to say that the reducing condition of the deeper part of Lake Kaiike is supported by the dense population of Chromatium sp. and the growth of the bacterium is also promoted by the underlying reducing condition, preferentially receiving the supply of $\mathrm{H}_{2} \mathrm{~S}$ and inorganic nutrients. Thus, it may be assumed that even if the stratification of Lake Kaiike should be broken for a while, soon after the restora- tion of stratification, an $\mathrm{O}_{2}$ deficient condition will inevitably appear near the bottom and it will be changed into a more reducing condition to accumulate $\mathrm{H}_{2} \mathrm{~S}$ and inorganic nutrients in conjunction with Chromatium sp. So, the fact that Chromatium sp. has always an important role in the whole organic matter production in the lake in spite of its relatively low growth rate may suggest that such a trophic structure reaches a stable state in the lake in virtue of the stratified condition.

\section{Acknowledgements}

The author wishes to express his thanks to 


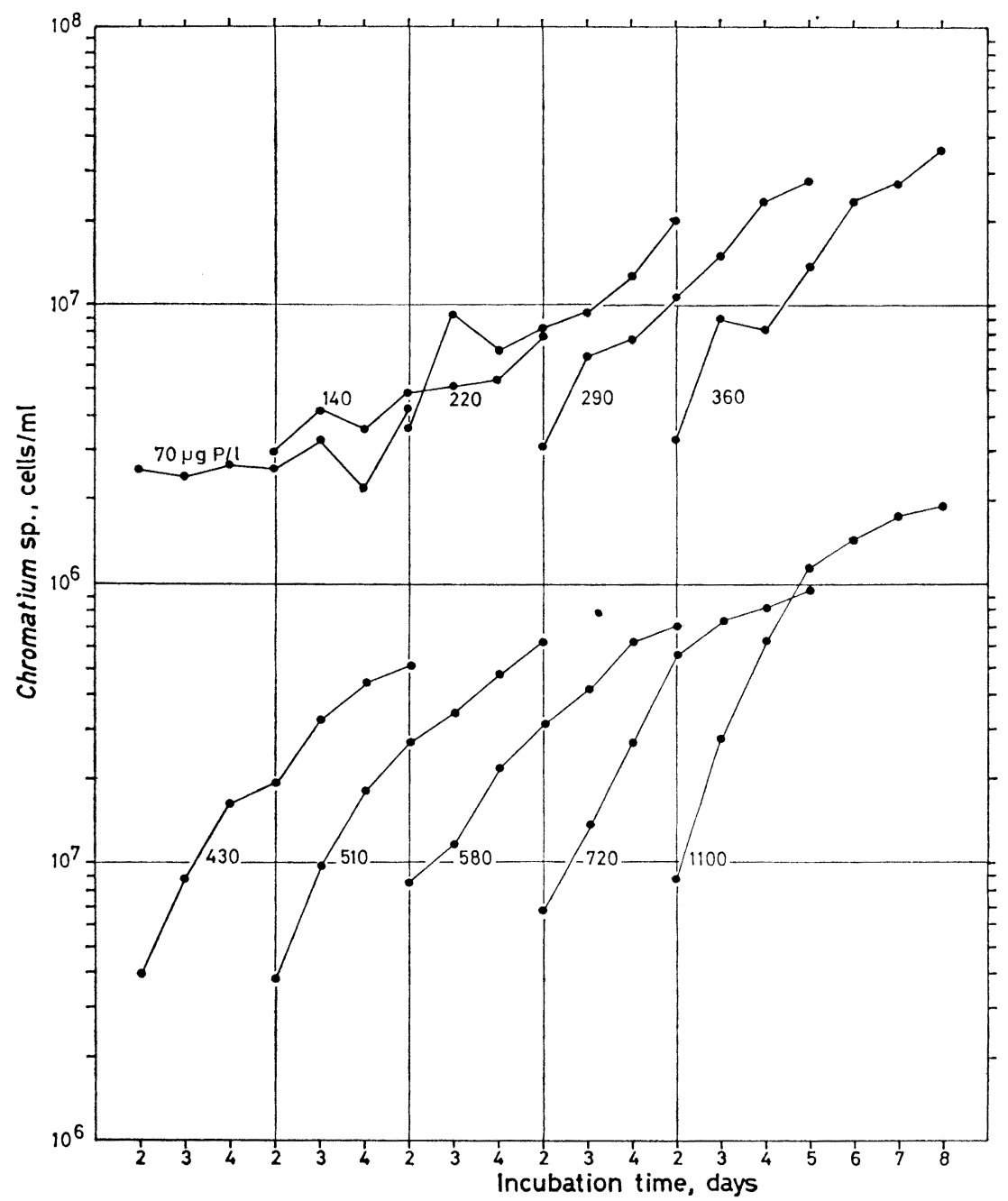

Fig. 8. Growth of Chromatium sp. incubated in the media to which different amounts of $\mathrm{PO}_{4}^{3-}$ were added. The horizontal line indicates the incubation time (days) after inoculation.

Profs. H. IrIE and S. IIzukA of Nagasaki University for their encouragement in the course of the work. The author is indebted to Messrs. T. Dahril, T. Sato and H. Fukui, students of Faculty of Fisheries, Nagasaki University, for their assistance in carrying out the observation of Lake Kaiike. The author's thanks are also due to the crew of the Kakusui for their hospitality rendered during the observation. This study was supported in part by the Science Research grant-in-aid of the Ministry of Education.

\section{摘 要}

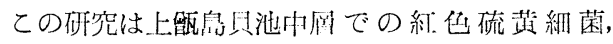
Chromatium sp. の密集分们について将祭した。 具 (1979年)，湖はよく成蔺し，上部 $\mathrm{O}_{2}$ 网之下部 $\mathrm{H}_{2} \mathrm{~S}$ 网 との境 $(4.75 \mathrm{~m})$ には Chromatium $\mathrm{sp}$. が湍密に分 仰 $\left(5 \times 10^{6} \mathrm{cells} / \mathrm{m} l\right)$ していた。至内灾験での Chromatium sp. の抽厓速度と $\mathrm{H}_{2} \mathrm{~S}$ 㴖度との双線阙 係は現場での同細菌の生应が罗元同からの $\mathrm{H}_{2} \mathrm{~S}$ の供 給に依存しているととを亦している。Chromatium sp. の目已遮へいによって巾回以深への光の透入が 抑制されるとと，同細菌の岑酸国定作用が湖内の全团 定昌で重要な部分を占めているととは下部の罚元状態 


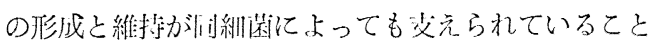
を示している。

\section{References}

American Public Health Association (1965): Standard method for the examination of water and wastewater. 12 ed., APHA

Bose, S. K. (1963): Media for anaerobic growth of photosynthetic bacteria. In $\mathrm{H}$. Gest et al., [eds.], Bacterial photosynthesis, 501-510.

Caldwell, D. E. and J.M. Tiedje (1975a) : A morphological study of anaerobic bacteria from the hypolimnia of two Michigan lakes. Can. J. Microbiol., 21: 362-376.

Caldwell, D. E. and J.M. Tiedje (1975b): The structure of anaerobic bacterial communities in the hypolimnia of several Michigan lakes. Can. J. Microbiol., 21: 377-385.

Cohen, Y., W. E. Krumbein, and M. Shilo (1977): Solar Lake (Sinai). 2. Distribution of photosynthetic microorganisms and primary production. Limnol. Oceanogr., 22: 609-620.

Culver, D. A. and G. J. Brunskill (1969): Fayetteville Green Lake, Nw York. V. Studies of primary production and zooplankton in a meromictic marl lakc. Limnol. Oceanorgr., 14: 862-873.

Czeczuga, B. (1968): An attempt to determine the primary production of the green sulphur bacteria, Chlorobium limicola Nads. (Chlorobacteriaccase). Hydrobiologia, 31:317-333.

FogG, G. E. (1965): Algal cultures and phytoplankton ecology. Univ. Wisconsin Press, Madison.

van Gemerden, H. (1968) : Utilization of reducing power in growing cultures of Chromatium. Arch. Mikrobiol., 64: 111-117.

van Gemerden, H. (1974): Coexistence of organisms competing for the same substrate; An example among the purple sulfur bacteria. Microbial Ecol., 1:104-119.

Goldman, J. C. and E. J. Carpenter (1974) A kinetic approach to the effect of temperature on algal growth. Limnol. Oceanogr., 19: 756-766.

Gorlenko, W. M. and S. I. Kuznetsov (1972) : Über die photosynthesierenden Bakterien des Kononier- Sees. Arch. Hydrobiol., 70:1-13. Gorlenko, V. M., M. B. Vanistein, and V. I.
Kachalkin (1978): Microbiological characteristics of lake Mogilnoye. Arch. Hydrobiol., 81: 475-492.

Hutchinson, G.E. (1967): A treatise on limnology. Vo1. 2. Wiley and Sons, New York.

Ichimura, S. (1965) : On the ecological meaning of transparency for the production of matter in phytoplankton community of lake. Eot. Mag. (Tokyo), 69: 219-226.

Ingvorsen, K. and B. B. Jørgensen (1979): Combined measurement of oxygen and sulfide in water samples. Limnol. Oceanogr., 24: 390-393.

Kuznetsov, S. I. and W. M. Gorlenko (1973) : Limnologische und mikrobiologische Eigenschaften von Karstseen der A. S. R. Mari. Arch. Hydrobiol,, 71: 475-486.

Matsuyama, M. and Y. Saijo (1971): Studies on biological metabolism in a meromictic Lake Suigetsu. J. Oceanog. Soc. Japan, 27: $197-206$.

Matsuyama, M. (1977): Limnological features of Lake Kaiike, a small coastal lake on Kamikoshiki Island, Kagoshima Prefecture, Japan. Jap. J. Limnol., 38: 9-18.

Matsuyama, M. (1978): Stratified condition of Lake Kaiike, a small coastal lake on Kamikoshiki Island, Kagoshima Prefecture. Jap. J. Limnol., 38: 97-102.

Matsuyama, M. and E. Shirouzu (1978): Importance of photosynthetic sulfur bactcria, Chromatium sp. as an organic matter producer in Lake Kaiike. Jap. J. Limnol., 3.9: 103-111.

Matsuyama, M. (1979): On the purple sulfur bacterium, Chromatium sp., densely populating the mid-depth of Lake Kaiike, Kamikoshiki Island, Kagoshima Prefecture. Jap. J. Limnol., 40: 20-28.

Oceanographical Society of Japan (1970): Kaiyo-kansoku-shishin (manual for oceanographical observations). Japan Meteological Agency. (in Japanese)

Richards, F.A., J.D. Cline, W. W. Broenkow, and L. P. Atrinson (1965) : Some consequences of the decomposition of organic matter in Lake Nitinat, an anoxic fjord. L.imnol. Oceanogr., 10: R185-201.

Steemann Nielden (1952): The use of radioactive 
$\mathrm{C}(\mathrm{C}-14)$ for measuring organic matter production in the sea. J. Conc. Int. Explor. Mer, 18: $117-140$.

Takahashi, M. and S. Ichimura (1970): Photosynthetic properties and growth of photosynthetic sulfur bacteria in lakes. Limnol. Oceanogr., 15: 929-944.

Trüpper, H. G. and H. G. Schlegel (1964) : Sulphur metabolism in Thiorhodaceae. I.
Quantitative measurements on growing cells of Chromatium okenic. Ant. Leeuwenhoek, 30: 225-238.

（著者：松山通郎, 長崎大学水産学部, 長崎市交教 町; Michiro Matsuyama, Faculty of Fisheries, Nagasaki University, Bunkyo-machi, Nagasaki 852)

Accepted: 16 January, 1980 